\title{
Synthesis of a Rhodamine-Appended Cyclophane as a Fluorescence Host in Water
}

\author{
Osamu Hayashida*, Yu Kaku \\ Department of Chemistry, Faculty of Science, Fukuoka University, Fukuoka, Japan \\ Email: ${ }^{\text {hayashida@fukuoka-u.ac.jp }}$
}

Received 8 July 2014; revised 8 August 2014; accepted 26 August 2014

Copyright (C) 2014 by authors and Scientific Research Publishing Inc.

This work is licensed under the Creative Commons Attribution International License (CC BY). http://creativecommons.org/licenses/by/4.0/

(c) (i) Open Access

\begin{abstract}
A cationic water-soluble cyclophane (1a) having a rhodamine moiety as a red-fluorescence fluorophore was prepared by reaction of a monoamine derivative of tetraaza[6.1.6.1]paracyclophane having three $\boldsymbol{N}$-t-butoxycarbonyl- $\beta$-alanine residues with rhodamine B isothiocyanate, followed by removal of the protecting groups. The guest-binding behavior of 1 a toward anionic guests such as dabsyl derivative and 4-(1-pyrene)butanoate was investigated by fluorescence spectroscopy. The results suggested the formation of host-guest complexes with a stoichiometric ratio of $1: 1$ and the binding constants $(K)$ of the host-guest complexes were evaluated.
\end{abstract}

\section{Keywords}

Host-Guest Chemistry, Water-Soluble Cyclophane, Fluorescent Sensing

\section{Introduction}

In recent years, much attention has been focused on development of fluorescent host sensor systems, which are able to detect small organic compounds [1]. Many types of fluorophore-appended macrocyclic hosts based on cyclodextrins [2], calixarenes [3], and cyclophanes [4] were widely investigated. Numerous successful studies of fluorophore-appended hosts based on these macrocyclic compounds were reported [5]. Among them, azacyclophanes [6] having a hydrophobic internal cavity are favorable candidates as the framework of macrocyclic host, because shape and size of the cavity can be easily designed for the capture of target guest molecules. In addition, exterior modifications of azacyclophanes can be achieved by the introduction of various functional groups such as polar side chains for water-solubility and fluorophores for fluorescent sensing onto the nitrogen atoms through an appropriate spacer [7]. In the preceding paper, we have developed water-soluble blue fluorescent cyclophanes [8], which are composed of a tetraaza[6.1.6.1]paracyclophane skeleton, three polar side chains for water-solu-

Corresponding author.

How to cite this paper: Hayashida, O. and Kaku, Y. (2014) Synthesis of a Rhodamine-Appended Cyclophane as a Fluorescence Host in Water. Advances in Chemical Engineering and Science, 4, 401-408.

http://dx.doi.org/10.4236/aces.2014.44044 
bility, and a pyrene fluorophore. The pyrene-appended cyclophanes showed characteristic fluorescence spectra originated from pyrene moiety in aqueous media upon irradiation with UV light [8]. A fluorescence intensity originated from the pyrene-appended host decreased upon addition of 8-anilino-naphthalene-1-sulfonate (ANS) as a guest [9], reflecting the formation of host-guest complexes [8].

On the other hand, many types of fluorescent dyes such as fluorescein isothiocyanate [10], rhodamine derivatives [11], and molecular beacons [12] have been designed and developed in order to investigate interactions of biomolecular complexes and assemblies. Among them, rhodamine derivatives emitting in the red region of visible spectrum are widely used as fluorescent labels for lipids, proteins, peptides, nucleic acids, and other biomolecules [13]. They display high absorption coefficients and emission in the visible region, high fluorescence quantum yields, and high chemical stability and photostability [11]. In the course of our ongoing research on cyclophanes capable of performing guest-inclusion and fluorescent sensing, we became interested in developing fluorescent cyclophanes emitting in longer wavelength ranges than UV waves. As a water-soluble red fluorescent cyclophane, we have now designed cationic cyclophane bearing a rhodamine moiety (1a) and analogous anionic cyclophane (1b) (Figure 1). We report here the synthesis of water-soluble cyclophane having a rhodamine moiety and its guest-binding abilities.

\section{Experimental Section}

\subsection{General Methods}

HEPES ( $N$-(2-hydroxyethyl) piperazine- $N$ '-2-ethanesulfonic acid) buffer (0.01 M, pH 7.4, with $0.15 \mathrm{M} \mathrm{NaCl}$ ) was purchased from GE Healthcare. A cyclophane derivative bearing $N$-protected amines (2) was prepared after a method reported previously [14]. Elemental analyses were recorded on a Yanako CHN Corder MT-5. ${ }^{1} \mathrm{H}$ and ${ }^{13} \mathrm{C}$ spectra were taken on Varian Mercury 400 spectrometer. Fluorescence spectra, IR spectra, and ESI TOF MS
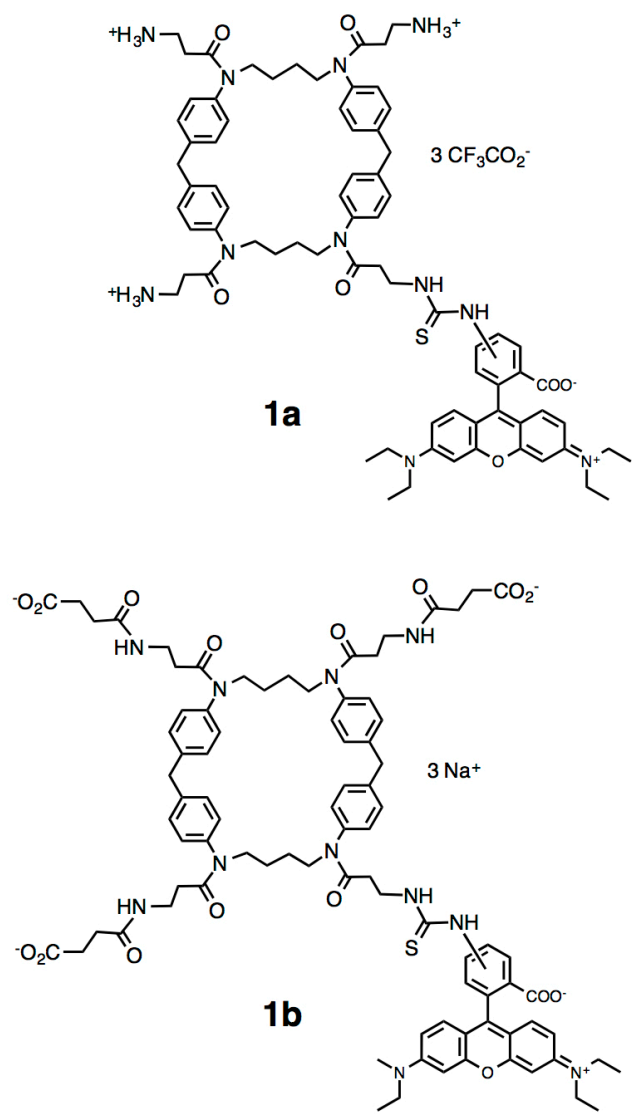

Figure 1. Cationic and anionic cyclophanes bearing a rhodamine moiety $\mathbf{1 a}$ and $\mathbf{1 b}$. 
were recorded on JASCO FP-750, Perkin-Elmer spectrum one, and JMS-T100 CS spectrometers, respectively.

\subsection{Precursor of 1 a (3)}

Piperidine $(1.0 \mathrm{~mL})$ was added to a solution of cyclophane derivative bearing $N$-protected amines (2) (179 mg, $0.14 \mathrm{mmol}$ ) in dry dichloromethane (DCM, $5 \mathrm{~mL}$ ), and the mixture was stirred for $5 \mathrm{~h}$ at room temperature. Then the solvent was evaporated off under reduced pressure to give a pale yellow solid (monoamine of cyclophane). The monoamine of cyclophane was purified by gel filtration chromatography on a column of Sephadex LH-20 with methanol as an eluant. The precursor fraction was evaporated to dryness under reduced pressure to give a pale yellow solid (cyclophane monoamine, $152 \mathrm{mg}$ ). Triethylamine was added to a solution of the monoamine of cyclophane $(140 \mathrm{mg}, 0.13 \mathrm{mmol})$ in dry DCM $(8 \mathrm{~mL})$ at room temperature, and the mixture was allowed to stand at same temperature. The mixture was added to a solution of rhodamine B isothiocyanate (91 mg, $0.17 \mathrm{mmol})$ in dry DCM (2 mL), and the resulting mixture was stirred for 1 day at the same temperature. After being dried $\left(\mathrm{Na}_{2} \mathrm{SO}_{4}\right)$, the solution was evaporated to dryness under reduced pressure to give a dark purple solid. The crude product was purified by gel filtration chromatography on a column of Sephadex LH-20 with methanol as an eluant. Evaporation of the product fraction under reduced pressure gave a dark purple solid (151 mg, $73 \%$ ): $\mathrm{mp} 144^{\circ} \mathrm{C}-145^{\circ} \mathrm{C} .{ }^{1} \mathrm{H}$ NMR (400 MHz, $\left.\mathrm{CDCl}_{3}, 293 \mathrm{~K}\right) \delta 1.3(\mathrm{~m}, 12 \mathrm{H}), 1.4(\mathrm{~m}, 35 \mathrm{H}), 2.1(\mathrm{~m}, 8 \mathrm{H}), 3.3(\mathrm{~m}, 8 \mathrm{H})$, $3.5(\mathrm{~m}, 8 \mathrm{H}), 3.6(\mathrm{~m}, 8 \mathrm{H}), 3.9(\mathrm{~m}, 4 \mathrm{H}), 5.3(\mathrm{~m}, 5 \mathrm{H}), 6.6(\mathrm{~m}, 4 \mathrm{H}), 7.0(\mathrm{~m}, 10 \mathrm{H}), 7.1(\mathrm{~m}, 10 \mathrm{H})$ and $7.5(\mathrm{~m}, 1 \mathrm{H}) .{ }^{13} \mathrm{C}$ NMR (100 MHz, $\left.\mathrm{CDCl}_{3}, 293 \mathrm{~K}\right) \delta$ 12.8, 25.1, 28.6, 35.0, 36.5, 40.3 - 41.5, 45.8, 48.9, 79.1, 96.2 - $96.9,112$ - 113 , 128 - 129, 130 - 131, 132, 140 - 141, 155, 156, 157, 171, 172 and 181. IR $1646 \mathrm{~cm}^{-1}$ (C=O). Found: C, 59.72; H, 7.47; N, 8.74. Calcd for $\mathrm{C}_{90} \mathrm{H}_{113} \mathrm{ClN}_{11} \mathrm{NaO}_{13}$ S. $9 \mathrm{H}_{2} \mathrm{O}$ : C, 59.74; H, 7.30; N, 8.51. ESI-TOF MS (positive mode): $\mathrm{m} / \mathrm{z} 1589[\mathrm{M}+\mathrm{H}]^{+}, 1611[\mathrm{M}+\mathrm{Na}]^{+}$, where $\mathrm{M}$ denotes zwitterionic form of cyclophane $\left(\mathrm{M}, \mathrm{C}_{90} \mathrm{H}_{113} \mathrm{~N}_{11} \mathrm{O}_{13} \mathrm{~S}\right)$.

\subsection{Cationic Cyclophane Bearing a Rhodamine Moiety (1a)}

Trifluoroacetic acid $(1.0 \mathrm{~mL})$ was added to a solution of CP-Boc3RhB (153 mg, $0.096 \mathrm{mmol})$ in dry DCM (6 $\mathrm{mL}$ ), and the mixture was stirred for $1 \mathrm{~h}$ at room temperature. Evaporation of the solvent under reduced pressure gave a dark purple solid. The crude product was purified by gel filtration chromatography on a column of Sephadex LH-20 with methanol as an eluant. Evaporation of the product fraction under reduced pressure gave a dark purple solid (139 mg, 89\%): $\mathrm{mp} 182^{\circ} \mathrm{C}-190^{\circ} \mathrm{C}$ (decomp.). ${ }^{1} \mathrm{H}$ NMR (400 MHz, CD $\left.\mathrm{CD}_{3} 293 \mathrm{~K}\right) \delta 1.1-1.2$ (m, 12H), 1.3 - $1.5(\mathrm{~m}, 8 \mathrm{H}), 2.2$ - $2.5(\mathrm{~m}, 8 \mathrm{H}), 2.9$ - $3.1(\mathrm{~m}, 8 \mathrm{H}), 3.5$ - $3.8(\mathrm{~m}, 16 \mathrm{H}), 3.9-4.1(\mathrm{~m}, 4 \mathrm{H}), 6.7$ - 7.0 $(\mathrm{m}, 8 \mathrm{H}), 7.1-7.4(\mathrm{~m}, 16 \mathrm{H})$ and $8.1(\mathrm{~m}, 1 \mathrm{H}) .{ }^{13} \mathrm{C}$ NMR (100 MHz, $\left.\mathrm{CD}_{3} \mathrm{OD}, 293 \mathrm{~K}\right) \delta 11.8,23.6-25.0,31.4,35.8$, 40.6, 45.5, 48.6, 95.8, 113 - 114, 116 - 121, 128 - 129, 130 - 131, 132, 139 - 141, 142, 155, 158, 161 - 162,170 and 181. IR $1645 \mathrm{~cm}^{-1}(\mathrm{C}=\mathrm{O})$. Found: C, 58.52; H, 6.00; N, 9.28. Calcd for $\mathrm{C}_{81} \mathrm{H}_{92} \mathrm{~F}_{9} \mathrm{~N}_{11} \mathrm{O}_{13} \mathrm{~S} \cdot 2 \mathrm{H} \mathrm{H}_{2} \mathrm{O}: \mathrm{C}, 58.37 ; \mathrm{H}$, 5.81; N, 9.24. ESI-TOF MS (positive mode): $\mathrm{m} / \mathrm{z} 1289[\mathrm{M}+\mathrm{H}]^{+}, 1311\left[\mathrm{M}+\mathrm{Na}^{+}\right.$, where $\mathrm{M}$ denotes triamine derivative of cyclophane as a free base $\left(\mathrm{M}, \mathrm{C}_{75} \mathrm{H}_{89} \mathrm{~N}_{11} \mathrm{O}_{7} \mathrm{~S}\right)$.

\subsection{Anionic Cyclophane Bearing a Rhodamine Moiety (1b)}

Succinic anhydride (59 mg, $0.59 \mathrm{mmol}$ ) was added to a solution of cyclophane 1a (106 mg, $0.06 \mathrm{mmol}$ ) and triethylamine $(0.5 \mathrm{~mL})$ in dry DCM $(4 \mathrm{~mL})$ at room temperature, and the mixture was stirred for 1 day. Ethylenediamine $(0.1 \mathrm{~mL}, 1.5 \mathrm{mmol})$ was added to the mixture to quench the reaction. After being dried $\left(\mathrm{Na}_{2} \mathrm{SO}_{4}\right)$, the solution was evaporated to dryness under reduced pressure to give a dark purple solid. The crude product was purified by gel filtration chromatography on a column of Sephadex LH-20 with methanol as an eluant. Evaporation of the product fraction under reduced pressure gave a dark purple solid. Then added $0.1 \mathrm{M} \mathrm{NaOH}$ aq. (2 ml) and stirred $20 \mathrm{~min}$ at room temperature. After dialysis (1.0 kDa cut-off) for $4 \mathrm{~h}$, the solvent was freeze-dried to gave a dark purple solid (88 mg, $82 \%$ ): $\mathrm{mp} 170^{\circ} \mathrm{C}-172^{\circ} \mathrm{C}$ (decomp.). ${ }^{1} \mathrm{H}$ NMR (400 MHz, $\left.\mathrm{CD}_{3} \mathrm{OD}, 293 \mathrm{~K}\right) \delta$ $1.0-1.5(\mathrm{~m}, 20 \mathrm{H}) 2.2(\mathrm{~m}, 6 \mathrm{H}), 2.4(\mathrm{~m}, 14 \mathrm{H}), 3.3(\mathrm{~m}, 8 \mathrm{H}), 3.4-3.8(\mathrm{~m}, 16 \mathrm{H}), 3.9-4.0(\mathrm{~m}, 4 \mathrm{H}), 6.8(\mathrm{~m}, 4 \mathrm{H}), 6.9$ - $7.1(\mathrm{~m}, 10 \mathrm{H}), 7.2-7.4(\mathrm{~m}, 8 \mathrm{H}), 7.7-7.9(\mathrm{~m}, 2 \mathrm{H})$ and $8.1(\mathrm{~m}, 1 \mathrm{H}) .{ }^{13} \mathrm{C}$ NMR $\left(100 \mathrm{MHz}, \mathrm{CD}_{3} \mathrm{OD}, 293 \mathrm{~K}\right) \delta 11.7$, 23.1, 23.9, 32.8, 33.5, 34.1, 35.4, 40.6, 45.6, 52.0, 96.0, 113, 114, 128 - 129, 130 - 131, 132, 140, 141 - 142, 155, 158, 171 - 172, 174 ,179, 180 and 181. IR 1736, $1635 \mathrm{~cm}^{-1}(\mathrm{C}=\mathrm{O})$. Found: C, 63.37; H, 6.35; N, 9.56. Calcd for $\mathrm{C}_{87} \mathrm{H}_{101} \mathrm{~N}_{11} \mathrm{O}_{16} \mathrm{~S} \cdot 3 \mathrm{H}_{2} \mathrm{O}$ : C, 63.60; H, 6.56; N, 9.38. ESI-TOF MS (negative mode): $\mathrm{m} / \mathrm{z} 1589$ [M - H] $]^{-}, 1610$ [M $-2 \mathrm{H}+\mathrm{Na}]^{-}, 1632[\mathrm{M}-3 \mathrm{H}+2 \mathrm{Na}]^{-}$, where $\mathrm{M}$ denotes carboxylic acid of cyclophane $\left(\mathrm{M}, \mathrm{C}_{87} \mathrm{H}_{101} \mathrm{~N}_{11} \mathrm{O}_{16} \mathrm{~S}\right)$. 


\section{5. $C$-Protected Dabsyl Guest (4)}

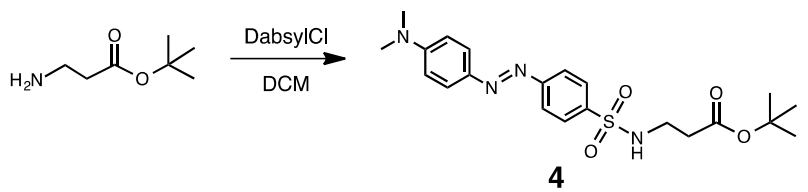

Triethylamine $(0.5 \mathrm{~mL}$ ) was added to a solution of $\beta$-alanine $t$-butyl ester hydrochloride (95 $\mathrm{mg}, 0.52 \mathrm{mmol})$ in dry DCM $(10 \mathrm{ml})$ at room temperature. The mixture was added to a solution of 4-dimethyl-aminoazobenzene4-sulfonyl chloride (DabsylCl, $149 \mathrm{mg}, 0.46 \mathrm{mmol}$ ) in dry DCM (5 ml), and the resulting mixture was stirred for day at room temperature. The residue was chromatographed on a column of silica gel $\left(\mathrm{SiO}_{2}\right)$ with chloroform-methanol $(95: 5 \mathrm{v} / \mathrm{v})$ as eluant. Evaporation of the product fraction under reduced pressure gave a orange-red solid (158 mg, 79\%): $\mathrm{mp} 170^{\circ} \mathrm{C}-171^{\circ} \mathrm{C} .{ }^{1} \mathrm{H}$ NMR (400 MHz, $\left.\mathrm{CDCl}_{3}, 293 \mathrm{~K}\right) \delta 1.4(\mathrm{~s}, 9 \mathrm{H}), 2.4(\mathrm{~m}$, $2 \mathrm{H}), 3.2(\mathrm{~m}, 6 \mathrm{H}), 3.5(\mathrm{~m}, 2 \mathrm{H}), 6.8(\mathrm{~m}, 2 \mathrm{H})$ and $7.9-8.0(\mathrm{~m}, 6 \mathrm{H}) .{ }^{13} \mathrm{C} \mathrm{NMR}\left(100 \mathrm{MHz}, \mathrm{CDCl}_{3}, 293 \mathrm{~K}\right) \delta 28.3$, 35.1, 39.2, 40.5, 81.8, 112, 122, 126, 140, 144, 153, 156 and 172. IR $1708 \mathrm{~cm}^{-1}(\mathrm{C}=\mathrm{O})$. Found: C, 57.11; $\mathrm{H}, 6.38$; $\mathrm{N}, 12.63$. Calcd for $\mathrm{C}_{21} \mathrm{H}_{28} \mathrm{~N}_{4} \mathrm{O}_{4} \mathrm{~S} \cdot 0.5 \mathrm{H}_{2} \mathrm{O}$ : C, 57.12; H, 6.62; N, 12.69. ESI-TOF MS (positive mode): $\mathrm{m} / \mathrm{z} 433$ $[\mathrm{M}+\mathrm{H}]^{+}, 455[\mathrm{M}+\mathrm{Na}]^{+}$.

\subsection{Anionic Dabsyl Guest (5)}

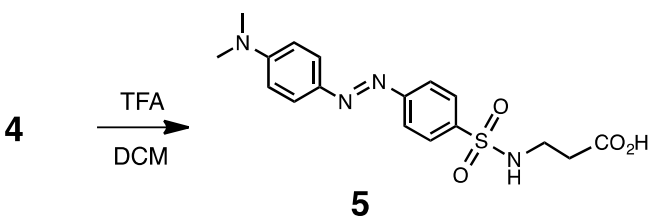

Trifluoroacetic acid $(1.0 \mathrm{ml})$ was added to a solution of $4(75 \mathrm{mg}, 0.17 \mathrm{mmol})$ in dry DCM (5 ml), and the mixture was stirred for $4 \mathrm{~h}$ at room temperature. The residue was chromatographed on a column of silica gel $\left(\mathrm{SiO}_{2}\right)$ with chloroform-methanol $(9: 1 \mathrm{v} / \mathrm{v})$ as eluant. The product fraction was evaporated to dryness under reduced pressure to give a orange-red solid (53 mg, 82\%): $\mathrm{mp} 164^{\circ} \mathrm{C}-165^{\circ} \mathrm{C} .{ }^{1} \mathrm{H}$ NMR $\left(400 \mathrm{MHz}, \mathrm{CD}_{3} \mathrm{OD}, 293 \mathrm{~K}\right) \delta 2.5$ $(\mathrm{m}, 2 \mathrm{H}), 3.1(\mathrm{~m}, 6 \mathrm{H}), 3.2(\mathrm{~m}, 2 \mathrm{H}), 6.9(\mathrm{~m}, 2 \mathrm{H})$ and $7.9-8.0(\mathrm{~m}, 6 \mathrm{H}) .{ }^{13} \mathrm{C}$ NMR $\left(100 \mathrm{MHz}, \mathrm{CD}_{3} \mathrm{OD}, 293 \mathrm{~K}\right) \delta$ 28.3, 35.1, 39.2, 40.5, 81.8, 112, 122, 126, 140, 144, 153, 156 and 172. IR $1709 \mathrm{~cm}^{-1}(\mathrm{C}=\mathrm{O})$. Found: C, 54.24; $\mathrm{H}, 5.36$; N, 14.88. Calcd for $\mathrm{C}_{17} \mathrm{H}_{20} \mathrm{~N}_{4} \mathrm{O}_{4} \mathrm{~S}$ : C, 54.00; H, 5.40; N, 15.11. ESI-TOF MS (positive mode): $\mathrm{m} / \mathrm{z} 377$ $[\mathrm{M}+\mathrm{H}]^{+}, 399[\mathrm{M}+\mathrm{Na}]^{+}$.

\subsection{Computational Procedure}

The calculations were carried out on a Pentium $43.2 \mathrm{GHz} \times 2$ machine using Macro Model 9.1 molecular modeling software on a Red Hat Enterprise Linux WS 4.3 operating system. The geometry of $1 \mathbf{a}$ and $\mathbf{1 b}$ was optimized using molecular mechanics employing the OPLS_2005 force field for the simulation of the hosts. The geometry was optimized without any constraints allowing all atoms, bonds, and dihedral angles to change simultaneously.

\subsection{Binding Constants of Cyclophanes with the Guests}

To each solution of fluorescent cyclophane $(0.5 \mu \mathrm{M})$ in HEPES buffer were added increasing amounts of 5 and 6, and the fluorescence intensity was monitored after each addition by excitation at $558 \mathrm{~nm}$. Aqueous stock solution of $\mathbf{5}$ was prepared after addition of $\mathrm{NaOH}$. The binding constants were calculated on the basis of the Benesi-Hildebrand method for titration data.

\section{Results and Discussion}

\subsection{Design and Synthesis of Rhodamine-Appended Cyclophanes}

From a viewpoint of development of cyclophanes emitting in the red region of visible spectrum, we have de- 
signed water-soluble cyclophanes having a rhodamine moiety. Actually, we have adopted a simple strategy to prepare rhodamine-appended cyclophanes by introducing a rhodamine moiety into tetraaza[6.1.6.1]paracyclophane [15] through a $\beta$-alanine spacer. Rhodamine-appended cyclophanes bearing cationic and anionic polar side chains 1a and $\mathbf{1 b}$, respectively, were synthesized by following the reaction sequence shown in Scheme 1. In the preceding paper, we have synthesized a cyclophane derivative bearing $N$-protected amines $\mathbf{2}$ as a key intermediate [14]. A precursor (3) of 1a was synthesized by a reaction of rhodamine B isothiocyanate (RITC) [16] with a monoamine derivative of cyclophane, which was easily prepared from $\mathbf{2}$ by removal of the Fmoc protecting group with piperidine, in a 73\% yield. Cationic cyclophane bearing a rhodamine moiety 1a was derived from $\mathbf{3}$ by a treatment with trifluoroacetic acid (TFA). Then, 1a was converted to a cyclophane having carboxylic acid residues $\mathbf{1 b}$ by a reaction with succinic anhydride. New compounds were fully characterized by means of spectroscopy $\left({ }^{1} \mathrm{H}\right.$ and ${ }^{13} \mathrm{C}$ NMR, and TOF-MS) and elemental analysis. Even though compounds $\mathbf{1 a}$ and $\mathbf{1 b}$ contain a hydrophobic cavity, both compounds were soluble in aqueous neutral media at biological $\mathrm{pH}$ owing to three polar side chains. From a practical standpoint, cyclophanes $\mathbf{1 a}$ and $\mathbf{1 b}$ had good $\mathrm{H}_{2} \mathrm{O}$-solubility of 0.27 and 0.38 $\mathrm{g} / \mathrm{mL}$, respectively. Judging from molecular mechanics studies of cyclophanes $\mathbf{1 a}$ and $\mathbf{1 b}$, both compounds provide a rigid internal cavity and the peripheral polar side chains with reasonably separated distances from the cavity (Figure 2). These results indicate that $\mathbf{1 a}$ and $\mathbf{1 b}$ having hydrophobic cavities were expected to act as water-soluble hosts.

\subsection{Guest-Binding Behavior of Cyclophanes}

As mentioned above, rhodamine derivatives have an intense visible absorption. Actually, rhodamine-appended water-soluble cyclophanes $\mathbf{1 a}$ and $\mathbf{1 b}$ had high absorption coefficients and absorption in the visible region owing to the rhodamine moieties. In addition, they showed fluorescence emission spectra originated rhodamine moieties with a fluorescence maximum at $579 \mathrm{~nm}$ in aqueous media in aqueous HEPES (2-[4-(2-hydroxyethyl)-1-piperazinyl]ethanesulfonic acid) buffer $(0.01 \mathrm{M}, \mathrm{pH}$ 7.4, $0.15 \mathrm{M}$ with $\mathrm{NaCl}$ ) at $298 \mathrm{~K}$ (Figure 3 for 1a). First, the guest-binding behavior of $\mathbf{1 a}$ toward anionic dabsyl derivative $\mathbf{5}$ as a dark quencher guest, was examined by fluorescence spectroscopy in aqueous HEPES buffer $(0.01 \mathrm{M}, \mathrm{pH} 7.4,0.15 \mathrm{M}$ with $\mathrm{NaCl})$. The fluorescence intensity originated from $\mathbf{1 a}$ at $579 \mathrm{~nm}$ decreased upon addition of $\mathbf{5}$, reflecting formation of $\mathbf{1 a} \cdot \mathbf{5} \mathrm{com}-$ plexes, as shown in Figure 3(a). The stoichiometry for the complex was confirmed to be 1:1 1a:5 by a Job plot (Figure 4(a)). The 1:1 binding constant $(K)$ of 1 a toward 5 was calculated to be $2.7 \times 10^{4} \mathrm{M}^{-1}$ on the basis of the Benesi-Hildebrand relationship. On the other hand, the $K$ value of anionic cyclophane $\mathbf{1 b}$ with the identical guest $\mathbf{5}$ was not determined due to the low affinity in HEPES buffer by the identical method. These results indicate that the electrostatic interaction between host and guest molecules is effective recognition factor for the

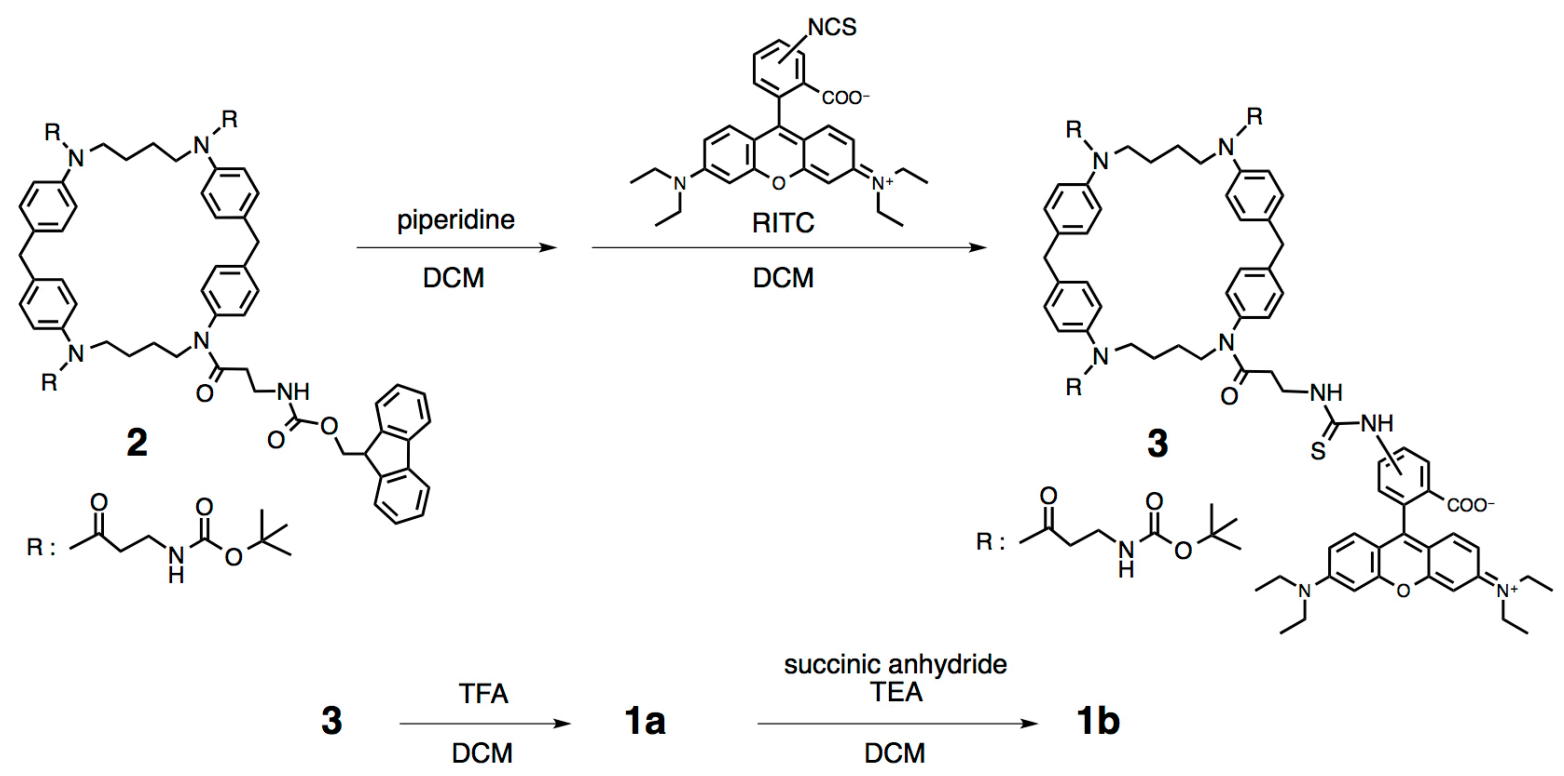

Scheme 1. Preparation of rhodamine-appended cyclophanes $\mathbf{1 a}$ and $\mathbf{1 b .}$ 
(a)

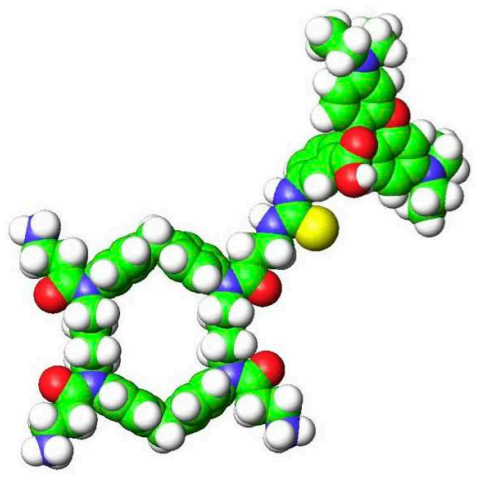

(b)

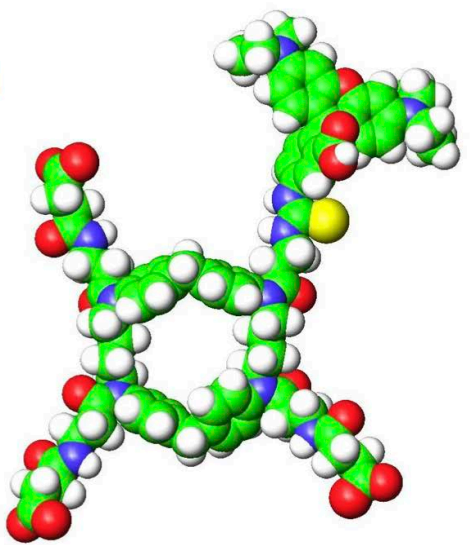

Figure 2. Computer-generated CPK models for 1a (a) and 1b (b). Carbon, hydrogen, oxygen, nitrogen, and sulfur atoms are shown in green, white, red, blue, and yellow respectively.

(a)

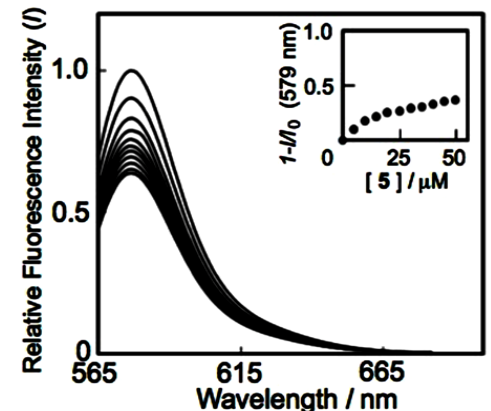

(b)

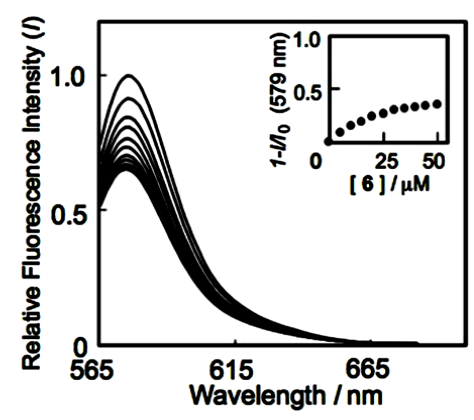

Figure 3. Fluorescence spectral changes for complexes of 1a with 5(a) and 6(b) in HEPES buffer (0.01 M, pH 7.4, $0.15 \mathrm{M}$ with $\mathrm{NaCL}$ ) at $298 \mathrm{~K}$. [1a] $=0.5 \mu \mathrm{M}$. [5] = [6] = 0, 5, 10, 15, 20, 25, 30, 35, 40, 45, and 50 $\mu \mathrm{M}$. (from top to bottom). Ex. $558 \mathrm{~nm}$. Insets: the corresponding titration curves.

host-guest complexation. A similar fluorescence feature was observed when 4-(1-pyrene)butanoate (6) was employed as an anionic florescence guest. That is, upon addition of $\mathbf{6}$ to an aqueous solution containing 1a, fluorescence intensity originated from 1a decreased, as shown in Figure 3(b), reflecting the formation of host-guest complexes. Such fluorescence quenching of $1 \mathbf{a}$ at $579 \mathrm{~nm}$ seems to be caused by the interactions between rhodamine group of 1a and entrapped pyrene molecule. The stoichiometry for the complex was also confirmed to be 1:1 1a:6 by a Job plot (Figure 4(b)). The $K$ value of $1 \mathbf{a}$ with $\mathbf{6}$ was calculated to be $2.9 \times 10^{4} \mathrm{M}^{-1}$, which was almost comparable to that of $\mathbf{1 a}$ with $\mathbf{5}$.

\section{Conclusion}

Rhodamine-appended cyclophanes bearing three cationic polar side chains 1a were successfully prepared by 

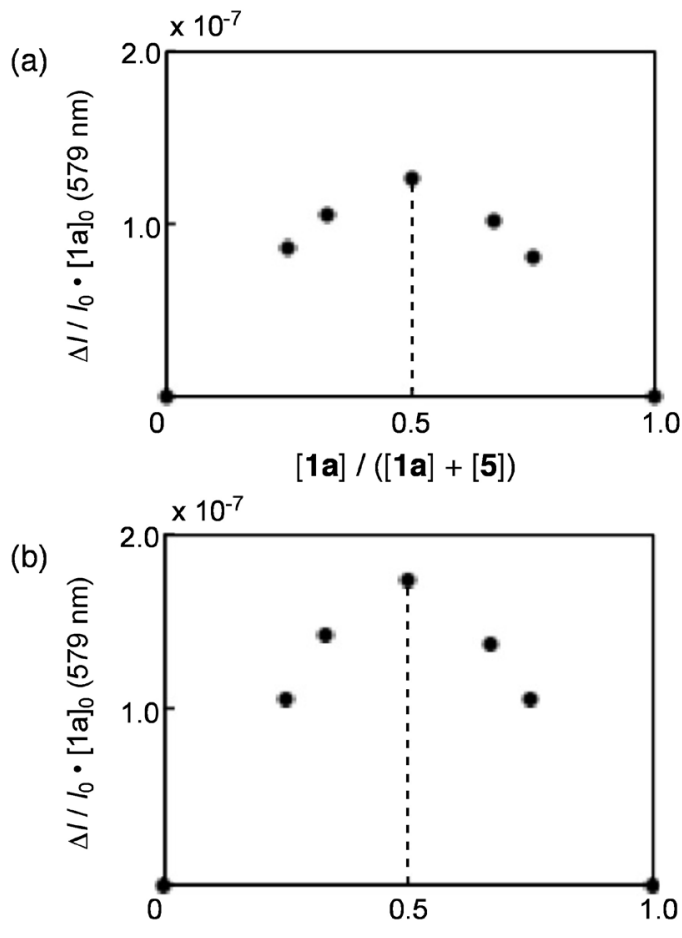

$[\mathbf{1 a}] /([\mathbf{1} \mathbf{a}]+[\mathbf{6}])$

Figure 4. Job's plots for complex of 1a and 5(a), 1a and 6(b): [1a] + [5] = [1a]

$+[6]=1.0 \mu \mathrm{M}$.

reaction of RITC with a monoamine derivative of cyclophane, followed by removal of the protecting groups in a fairly good yield. 1a showed fluorescence bands with a fluorescence maximum at $579 \mathrm{~nm}$ in an aqueous HEPES buffer. Formation of the host-guest complexes of the present cyclophane with anionic guests was demonstrated by fluorescence quenching experiments. The fluorescence intensity originating from 1a was subjected to decrease, upon complexation with anionic guests such as $\mathbf{5}$ and $\mathbf{6}$.

\section{Acknowledgements}

The present work is partially supported by Grant-in-Aid (No. 24550166) from the Ministry of Education, Culture, Science, Sports and Technology of Japan.

\section{References}

[1] Langton, M.J. and Beer, P.D. (2012) Sulfate-Selective Binding and Sensing of a Fluorescent [3]Rotaxane Host System. Chemistry - A European Journal, 18, 14406-14412. http://dx.doi.org/10.1002/chem.201202204

[2] Pagliari, S., Corradini, R., Galaverna, G., Sforza, S., Dossena, A., Montalti, M., Prodi, L., Zaccheroni, N. and Marchelli, R. (2004) Enantioselective Fluorescence Sensing of Amino Acids by Modified Cyclodextrins: Role of the Cavity and Sensing Mechanism. Chemistry - A European Journal, 10, 2749-2758. http://dx.doi.org/10.1002/chem.200305448

[3] Ocak, U., Ocak, M., Surowiec, K., Liu, X. and Bartsch, R.A. (2009) Metal Ion Complexation in Acetonitrile by Upper-Rim Allyl-Substituted, Di-Ionized Calix[4]Arenes Bearing Two Dansyl Fluorophores. Tetrahedron, 65, 7038-7047. http://dx.doi.org/10.1016/j.tet.2009.06.038

[4] Hayashida, O. and Hamachi, I. (2004) Fluorophore Appended Saccharide Cyclophane: Self-Association, Fluorescent Properties, Heterodimers with Cyclodextrins, and Cross-Linking Behavior with Peanut Agglutinin of Dansyl-Modified Saccharide Cyclophane. The Journal of Organic Chemistry, 69, 3509-3516. http://dx.doi.org/10.1021/jo0496852

[5] Saha, S., Ravikumar, I. and Ghosh, P. (2011) A Fluorophoric-Axle-Based, Nonfluororescent, Metallo anti-[3]Pseudorotaxane: Recovery of Fluorescence by Means of an Axle Substitution Reaction. Chemistry - A European Journal, 17, 1371213719. http://dx.doi.org/10.1002/chem.201102627 
[6] Odashima, K., Itai, A., Iitaka, Y. and Koga, K. (1985) Biomimetic Studies Using Artificial Systems. 3. Design, Synthesis, And Inclusion Complex Forming Ability of A Novel Water-Soluble Paracyclophane Possessing Diphenylmethane Skeletons. The Journal of Organic Chemistry, 50, 4478-4484. http://dx.doi.org/10.1021/jo00223a013

[7] Hayashida, O., Ogawa, N. and Uchiyama, M. (2007) Surface Recognition and Fluorescence Sensing of Histone by Dansyl-Appended Cyclophane-Based Resorcinarene Trimer. Journal of the American Chemical Society, 129, 1369813705. http://dx.doi.org/10.1021/ja074906h

[8] Hayashida, O., Eguchi, C., Kimura, K., Oyama, Y. and Shioji, K. (2010) Guest Binding, Cellular Uptake, and Molecular Delivery of Water-Soluble Cyclophanes Having a Pyrene Moiety. Chemistry Letters, 39, 1321-1322. http://dx.doi.org/10.1246/cl.2010.1321

[9] Slavik, J. (1982) Anilinonaphthalene Sulfonate as a Probe of Membrane Composition and Function. Biochimica et Biophysica Acta - Reviews on Biomembranes, 694, 1-25.

[10] Patra, D., Ozdemir, F., Miranda, O.R., Samanta, B., Sanyal, A. and Rotello, V.M. (2009) Formation and Size Tuning of Colloidal Microcapsules via Host-Guest Molecular Recognition at the Liquid-Liquid Interface. Langmuir, 25, 1385213854. http://dx.doi.org/10.1021/la9015756

[11] Bindman, N.A. and van der Donk, W.A. (2013) A General Method for Fluorescent Labeling of the N-Termini of Lanthipeptides and Its Application to Visualize Their Cellular Localization. Journal of the American Chemical Society, 135, 10362-10371. http://dx.doi.org/10.1021/ja4010706

[12] Wu, J., Zou, Y., Li, C., Sicking, W., Piantanida, I., Yi, T. and Schmuck, C. (2012) A Molecular Peptide Beacon for the Ratiometric Sensing of Nucleic Acids. Journal of the American Chemical Society, 134, 1958-1961. http://dx.doi.org/10.1021/ja2103845

[13] Liu, D., Wang, S., Swierczewska, M., Huang, X., Bhirde, A.A., Sun, J., Wang, Z., Yang, M., Jiang, X. and Chen, X. (2012) Highly Robust, Recyclable Displacement Assay for Mercuric Ions in Aqueous Solutions and Living Cells. ACS Nano, 6, 10999-11008. http://dx.doi.org/10.1021/nn3046192

[14] Hayashida, O. and Kaku, Y. (2013) Synthesis of Dabsyl-Appended Cyclophanes and Their Heterodimer Formation with Pyrene-Appended Cyclophanes. The Journal of Organic Chemistry, 78, 10437-10442. http://dx.doi.org/10.1021/jo4018843

[15] Odashima, K., Itai, A., Iitaka, Y., Arata, Y. and Koga, K. (1980) Inclusion Complex Formation in A Particular Geometry by A Water-Soluble Paracyclophane in Aqueous Solution-NMR Studies. Tetrahedron Letters, 21, 4347-4350. http://dx.doi.org/10.1016/S0040-4039(00)77854-3

[16] Goncalves, M.S.T. (2009) Fluorescent Labeling of Biomolecules with Organic Probes. Chemical Reviews, 109, 190212. 
Scientific Research Publishing (SCIRP) is one of the largest Open Access journal publishers. It is currently publishing more than 200 open access, online, peer-reviewed journals covering a wide range of academic disciplines. SCIRP serves the worldwide academic communities and contributes to the progress and application of science with its publication.

Other selected journals from SCIRP are listed as below. Submit your manuscript to us via either submit@scirp.org or Online Submission Portal.
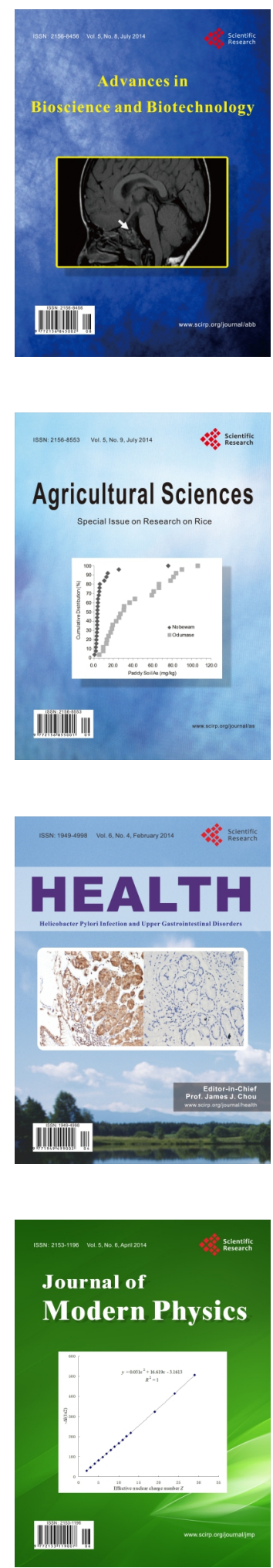
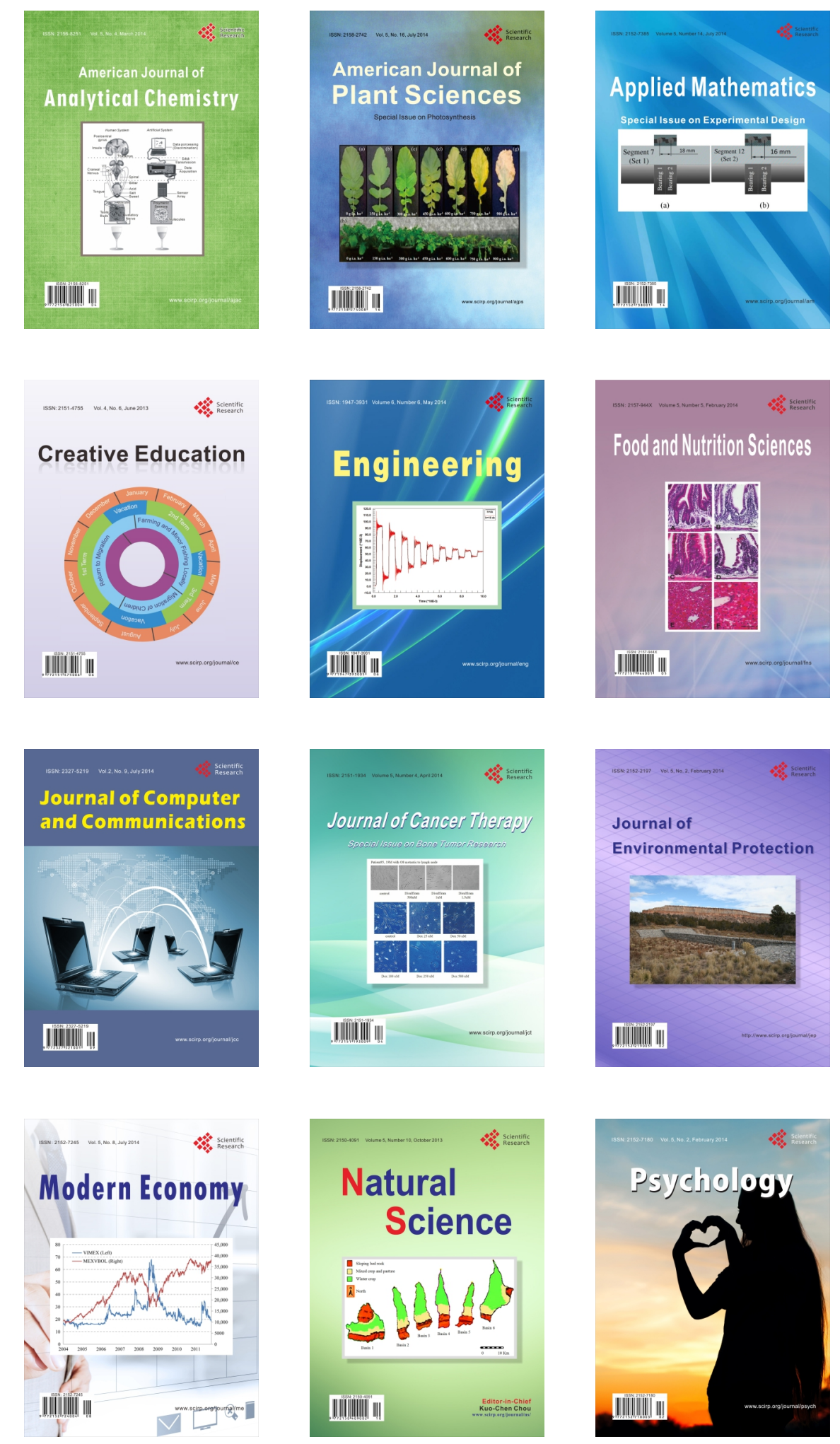